\title{
The impact of phasing out fossil fuel subsidies on the low-carbon transition
}

\author{
Irene Monasterolo ${ }^{\mathrm{a}}$, Marco Raberto ${ }^{\mathrm{b}}$ \\ a Vienna University of Economics and Business, University, \\ ${ }^{\mathrm{b}}$ DIME - University of Genoa, Italy
}

\section{A R T I C L E IN F O}

\section{Keywords:}

Fossil fuels subsidies

Renewable energy

Green energy policies

Green bonds

Stock-Flow Consistency

Distributive effects.

\begin{abstract}
A B S T R A C T
There is growing consensus on the fact that fossil fuels subsidies provided by governments in high-income countries represent a misalignment on emissions' reduction with the global climate agenda. In addition, a discussion emerged on the negative socio-economic and environmental externalities associated with fossil fuel subsidies. Nevertheless, pathways for phasing out fossil fuel subsidies in high income countries and their implications on the low-carbon transition have not yet been analysed. With the aim to narrow this knowledge gap, we extend the EIRIN Stock-Flow Consistent behavioral model to study the implications on sustainable development of the gradual phasing out of fossil fuels subsidies, whose revenues could be used by the government to subsidize energy investments in green capital (e.g. solar panels), either via fiscal policies or green bonds. We assess the effects on green growth, employment, credit and bonds market, as well as the distributive effects across heterogeneous households and sectors. The phasing out of fossil fuels subsidies contributes to improve macroeconomic performance, to decrease inequality and helps the government to find fiscal space to support stable renewable energy policies. Green subsidies contribute to foster the low-carbon transition but could imply distributive effects, depending on the way in which they are implemented.
\end{abstract}

\section{Introduction}

The UNFCCC COP21 climate conference in Paris reached the remarkable "Paris Agreement" aimed to limit global temperature increase "well below $2{ }^{\circ} \mathrm{C}$ above pre-industrial levels" (UNFCCC 2015). Complying with the Paris Agreement requires the introduction of climate and energy policies to decrease emissions concentration in the atmosphere and reach zero net Greenhouse Gases (GHG) emissions before the end of the century (Fay et al., 2015; IPCC, 2014). This implies that circa $3 / 4$ of proven reserves of coal, oil, and natural gas should be left in the ground (McGlade and Ekins, 2014). Unburnable fossil fuels' reserves (Leaton, 2012) could induce losses for the companies who own them, who transform them in energy and who use them for their final goods production, as well as for investors who are exposed to such companies. This concept is known as carbon stranded assets (Caldecott and McDaniels, 2014). Global GDP losses from carbon stranded assets have been estimated between USD 1-4 trillion (tn), a loss comparable to that of the last financial crisis (Marques et al., 2018). Given the considerable exposure of investors' portfolios to carbon-intensive sectors, and the deep interconnectedness of financial actors, destabilizing effects on the financial system could emerge (Battiston et al., 2017).
Despite this evidence, governments continue to heavily subsidize fossil fuels (Bast et al., 2015), also in the European Union (EU, Gencsu and Zerzawy, 2017). This is a main source of policy inconsistency with the global climate goals, with important negative socio-economic and environmental effects (Gerasimchuk et al., 2017). In order to inform policy-makers on potential pathways of energy subsidies' reforms and on their overall implications, improvements on state of the art modelling are needed. Indeed, traditional economic models used to assess the economic impact of energy and climate policies have several limitations to analyze complex systems characterized by heterogeneous agents, non-linearity, feedback loops. Understating such elements could influence models' outcomes in a crucial way, leading to a false sense of control.

With the aim to provide policy-makers relevant information on the economic, financial and distributive effects of phasing out fossil fuels subsidies in high-income countries, we enrich the EIRIN Stock-Flow Consistent (SFC) behavioral model (Monasterolo and Raberto, 2018) with an energy sector and an energy market. EIRIN is shaped on a high-income country of the EU, which signed the Paris Agreement, is

Email address: irene.monasterolo@wu.ac.at (I. Monasterolo) 


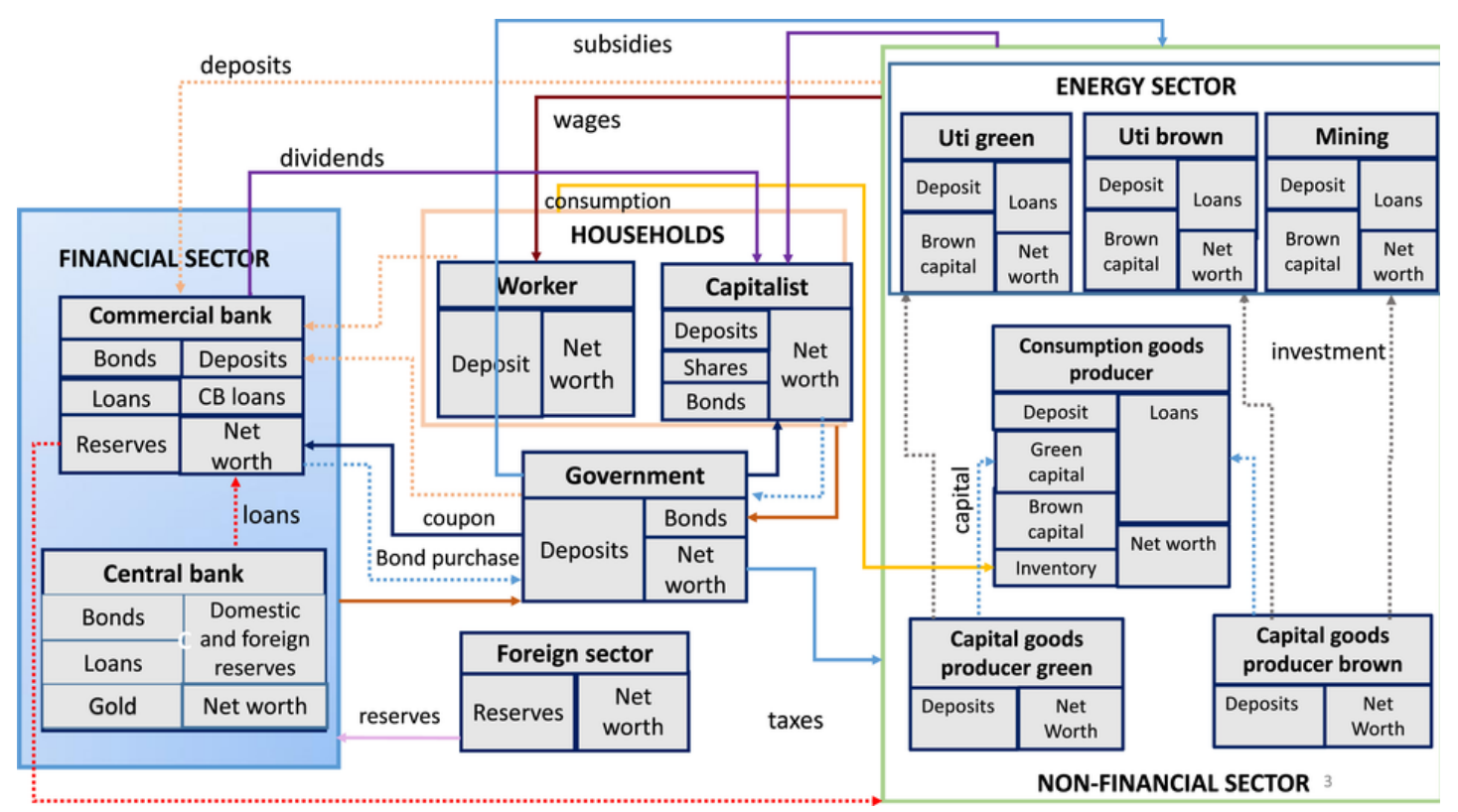

Fig. 1. Capital and current account flows of the EIRIN economy.

committed to the EU2030 targets and has a high level of energy dependency. ${ }^{1}$

With EIRIN, we compare scenarios characterized by a gradual phasing out of fossil fuel subsidies with scenarios characterized by the gradual phasing in of green energy policies, financed by the government either via fiscal measures or via the issuance of green sovereign bonds. For each energy policy scenario, we discuss the results in terms of macroeconomic performance, government budget balance, and the timing and magnitude of the low-carbon energy transition. Then, as a main added value on existing models, we assess the implications of each scenario on the credit and bonds market, and on the conditions for distributive effects to arise across heterogeneous households and sectors.

The paper is organized as follows. Section 2 introduces the state of the art on energy subsidies and their implications, while Section 3 presents the advances on energy subsidies' modelling. Section 4 introduces the extended EIRIN model, Section 5 discusses the policy scenarios, and Section 6 analyses the simulations' results. Section 7 concludes providing evidence-based recommendations for reforming energy policies.

\section{The state of global energy subsidies}

\subsection{Follow the money: fossil fuel subsidies $v$ s. renewable energy subsidies}

There is growing agreement on the fact that the lack of a stable and coherent climate and energy policy framework (Maxton and Randers 2017) and the presence of fossil fuel subsidies represent a serious obstacle to renewable energy investments (Stiglitz et al., 2017). While in the G20 countries renewable energy policies have been characterized by regulatory uncertainty and lack of coordination, producers and consumers of fossil fuels benefit at different extent from stable public support. Whitley and van der Burg (2015) estimated fossil fuel subsidies at USD 700 billion (bn) in 2015, while Coady et al. (2017) estimated them in USD 0.5 tn pre-tax. Including implicit subsidies (i.e. the value of the negative externalities produced by fossil fuel combustion, e.g.

1 We can take Italy as an example. Italy's energy dependency rate was $77.5 \%$ in 2016 (Eurostat), and more than a third of energy import is represented by natural gas. health problems and pollution), the amount reaches USD 5.3 tn in 2015. Bast et al. (2015) shows that G20 governments provided USD 444 bn a year in subsidies for the production of fossil fuels in 2013 and $2014 .^{2}$ This is almost four times the amount that the IEA estimates in all global subsidies to renewable energy in 2013 (IEA, 2015). A growing number of low-income and emerging countries started the phasing out of fossil fuel subsidies, and some even included fossil fuel subsidy reforms in their Nationally Determined Contributions (e.g. Egypt and Saudi Ara$\mathrm{bia}^{3}$ ). However, in high-income countries there is still no successful experience of phasing out fossil fuel subsidies. Between 2014 and 2016, 11 European governments and the EU provided at least $€ 112$ billion fossil fuel subsidies per year between (Gencsu and Zerzawy 2017).

Fossil fuel subsidies could target either energy consumption or production. Consumption subsidies arise when the price paid by consumers is below the cost of supply (Coady et al., 2017) and are commonly used by governments in low-income and emerging countries to decrease households' energy bills. Nevertheless, subsidies' benefits tend to be concentrated on the richest households, thus limiting the effect on energy poverty (Dartanto, 2013; Soile and Mu, 2015).

In contrast, by acting on the supply-side, production subsidies contribute to keep the price of fossil fuel extraction and energy production lower than the market price, thus increasing the profitability of mining and utility companies. Production subsidies also include subsidized inputs, preferential tax treatment or direct budget transfers. However, information on production subsidies is difficult to obtain because it requires access to data on fiscal revenues that is generally not available.

\subsection{Socio-economic and environmental implications of fossil fuel subsidies}

Fossil fuel subsidies have been recently questioned for the negative effects on the correct functioning of the market economy, the implications on political and social stability, and the negative socio-economic and environmental externalities.

2 The value of fossil fuel subsidies is uncertain due to the lack of transparency on data and due to the different methods used to carry on the estimates.

3 http://www.worldbank.org/en/news/feature/2017/11/21/

reforming-fossil-fuel-subsidies-for-a-cleaner-future. 
Table 1

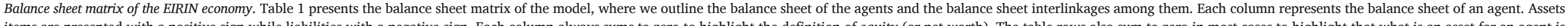

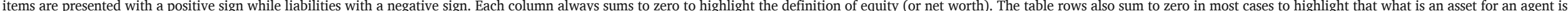
a liability for another agent.

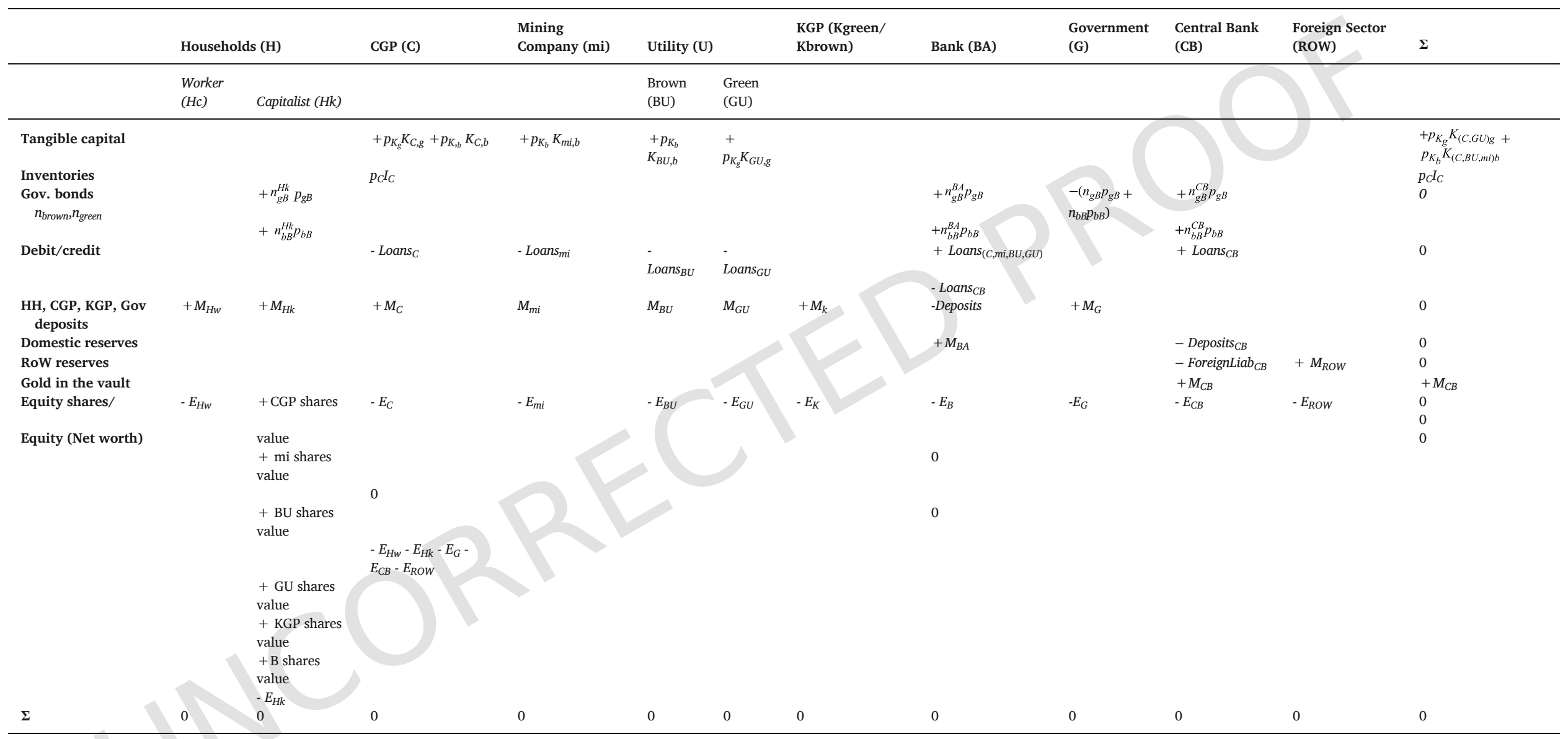

Bonds:

- brown included for Central Bank and commercial bank

- green included for KK and Central Bank

Equity: we add equity fo

mining

uti green 
Table 2

List of model's parameters related to the energy market. The list of models' parameters related to the original model's agents and sectors is provided in Monasterolo and Raberto (2018).

\begin{tabular}{|c|c|c|}
\hline Symbol & Scope & Value \\
\hline \multirow[t]{2}{*}{$\varepsilon_{s p}$} & amount of energy produced per solar panel & 0.01 \\
\hline & & e.u. \\
\hline \multirow[t]{2}{*}{$\varepsilon_{o}$} & amount of energy produced per unit of oil & 10 \\
\hline & & e.u. \\
\hline$\mu_{e}$ & mark-up on energy unit costs & $10 \%$ \\
\hline$\mu_{o}$ & growth rate of oil price & $0.0 \%$ \\
\hline$\gamma_{G}$ & percentage of labour force employed in the public sector & $20 \%$ \\
\hline$\gamma_{O}$ & $\begin{array}{l}\text { percentage of ownership of the mining company by the } \\
\text { foreign sector (ROW) }\end{array}$ & $100 \%$ \\
\hline$\alpha_{G U}$ & maximum allowed leverage for the green utility & 1 \\
\hline
\end{tabular}

From an economic point of view, fossil fuel subsidies introduce a distortion to the efficient functioning of the market. On the supply-side, by keeping the cost of fossil fuels artificially low, subsidies increase fossil fuel investments' profitability, influencing investors' behaviours and expectations, and preventing them to correctly price risks and returns associated to different energy technologies and investments. On the demand-side, they promote the consumption of fossil fuels in comparison to other energy sources (Davis, 2014). In addition, subsidies have distributive effects in the economy because governments usually finance them by increasing fiscal pressure, which disproportionally affects low-income households, being fiscal systems in high-income countries mostly regressive. Dennis (2016) showed that the welfare impact of phasing out fossil fuel subsidies is generally positive for governments and households. Further, fossil fuel subsidies exacerbate the negative impact of trade on climate change (Monasterolo and Raberto, 2016).

From a societal point of view, fossil fuel subsidies contribute to drag financial resources away from other sources of spending aimed at supporting sustainable and inclusive development, and contribute to wealth concentration by representing a linear income transfer to fossil fuel producers. If stabilized, fossil fuel subsidies eventually create addiction in the population and their reform could mine political stability (e.g. in the Gulf countries, Burniaux and Chateau, 2014, Lilliestam and Patt, 2015).
From an environmental point of view, fossil fuel subsidies contribute to increase $\mathrm{CO} 2$ emissions concentration in the atmosphere, discouraging investments in carbon-neutral technologies (Hoffert, 2010) and compromising the achievement of climate goals (Verkuijl et al., 2018). Then, both fossil fuel exploration and extraction activities are subject to accidents that could affect biodiversity and ecosystems with irreversible damages.

Therefore, reforming fossil fuel energy subsidies is important for the low-carbon transition, but it is hard to achieve both in fossil fuel rich and poor countries, for different reasons. On the one hand, fossil fuel rich countries rely on them for a disproportionate share of their GDP and fiscal revenues. On the other hand, in fossil fuel poor countries, production subsidies contribute to develop local utility companies and create internal energy supply. In addition, there is an issue of policy feasibility in so far fossil fuel reforms could translate into a visible loss of wealth concentrated in a few mighty investors who may then oppose the policy (Olson, 1977; Trebilcock, 2014). As a consequence, governments are usually reluctant to phase out subsidies, despite their negative effects on global carbon emissions and air pollution deaths, social welfare, and inequality (del Granado et al., 2012).

\section{Advances on the assessment of the economic and financial impacts of fossil fuel subsidies}

The quantitative assessment of the phasing out of fossil fuel subsidies has only recently started, with uneven results. Coady et al. (2017) find that eliminating post-tax energy subsidies would increase government revenues by USD 2.9 tn and would decrease global annual CO2 emissions by more than $20 \%$, with benefits on premature deaths from air pollution, that would be cut by more than half. In contrast, Jewell et al. (2018) find that the phasing out of fossil fuel subsidies in low-income countries would have low impact on the reduction of $\mathrm{CO} 2$ emissions and on renewable energy production. Their results are influenced by the fact that coal, which is the most polluting fossil fuel, is generally less subsidized than oil and gas, and the overall amount of direct fossil fuel subsidies decreased in the last five years (Parry, 2018).

By developing a global System Dynamics (SD) model, Gerasimchuk et al. (2017) assess both the first and second order impacts of phasing out fossil fuel subsidies at the global level. The authors find that higher

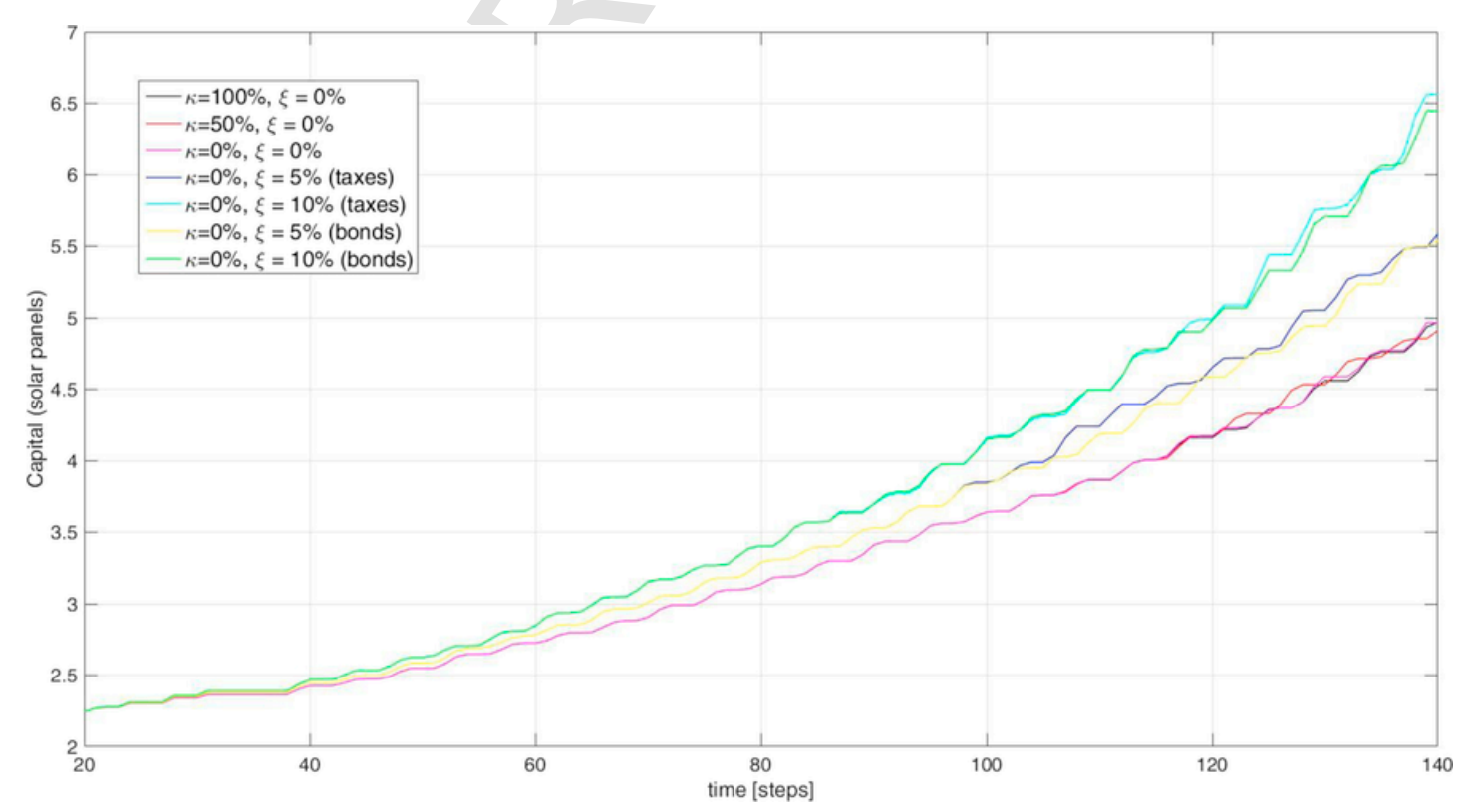

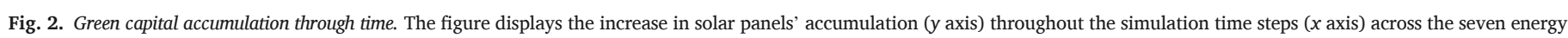
policy scenarios. 

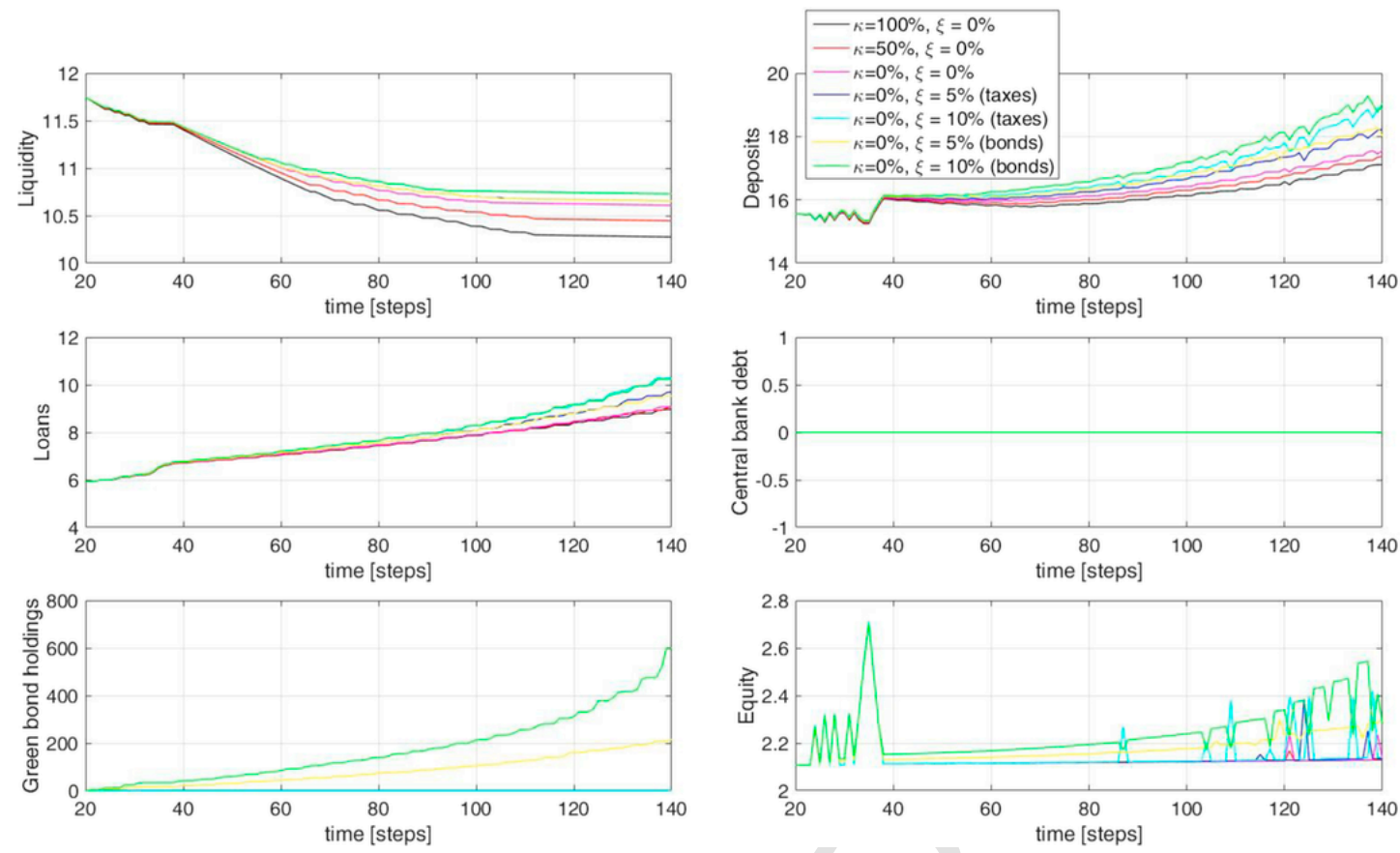

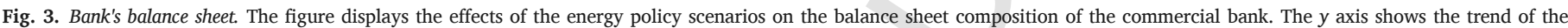
relevant variables, while the $x$ axis shows the time steps.

Table 3

Energy policy scenarios classified according to their impacts.

\begin{tabular}{|c|c|c|c|c|}
\hline \multirow[t]{2}{*}{ Impacts } & \multicolumn{2}{|l|}{ Positive } & \multicolumn{2}{|l|}{ Negative } \\
\hline & Low & High & Low & High \\
\hline $\begin{array}{l}\text { Real } \\
\text { economy }\end{array}$ & $\begin{array}{l}\text { Green tax/ } \\
\text { bond subsidy } \\
=5 \% \text { (blue, } \\
\text { yellow) }\end{array}$ & $\begin{array}{l}\text { Green tax/ } \\
\text { bond subsidy } \\
=10 \% \\
\text { (green, cyan) }\end{array}$ & $\begin{array}{l}\text { No energy } \\
\text { subsidy } \\
\text { (pink) }\end{array}$ & $\begin{array}{l}\text { Full fossil } \\
\text { fuel subsidy } \\
\text { (black) }\end{array}$ \\
\hline $\begin{array}{r}\text { Green capital } \\
\text { investment }\end{array}$ & $\begin{array}{l}\text { Green tax/ } \\
\text { bond subsidy } \\
=5 \% \text { (blue, } \\
\text { yellow) }\end{array}$ & $\begin{array}{l}\text { Green tax/ } \\
\text { bond subsidy } \\
=10 \% \\
\text { (green, cyan) }\end{array}$ & $\begin{array}{l}\text { No energy } \\
\text { subsidy } \\
\text { (pink) }\end{array}$ & $\begin{array}{l}\text { Phasing out } \\
\text { fossil fuel } \\
\text { subsidies } \\
=50 \% \text { (red) }\end{array}$ \\
\hline $\begin{array}{l}\text { Credit } \\
\text { market }\end{array}$ & $\begin{array}{l}\text { Green tax/ } \\
\text { bond subsidy } \\
=5 \% \text { (blue, } \\
\text { yellow) }\end{array}$ & $\begin{array}{l}\text { Green bond } \\
\text { subsidy } \\
=10 \% \\
\text { (green) }\end{array}$ & $\begin{array}{l}\text { Phasing out } \\
\text { fossil fuel } \\
\text { subsidies } \\
=50 \% \text { (red) }\end{array}$ & $\begin{array}{l}\text { Full fossil } \\
\text { fuel subsidy } \\
\text { (black) }\end{array}$ \\
\hline
\end{tabular}

fossil fuel prices encourage energy efficiency and the substitution of fossil fuels with alternative energy, thus resulting in net emission reductions over 2017-2050. Finally, Schwanitz et al. (2014) use the global energy-economy model REMIND and find that phasing out fossil fuel subsidies has a positive effect on the low-carbon economy. However, stable climate mitigation policies are required to sustain the benefits in the long-term.

Traditional economic models used to assess the economic impact of energy and climate policies are limited in the analysis of their distributive and financial impacts . Being solved to equilibrium, they are not suited to study the low-carbon transition as a policy-driven disequilibrium event where the new "steady state" of the economy may not be reached even for many decades. Then, they overlook the role of the credit market and the financial sector, thus neglecting amplification effects that could emerge between interconnected real economy and financial agents. In particular, they don't consider the economic role of central banks and governments in the economy, despite both play a key role respectively through their monetary and fiscal policies, in case of macroeconomic imbalances. In addition, strong assumptions on agents' representativeness and rationality, and their aggregate nature, make it difficult to assess the policies' distributive effects on heterogeneous households and sectors of real world societies. Furthermore, they tend to focus only on the direct effects of the policies on the specific institutional sector they target, neglecting possible feedbacks between sectors, thus preventing a comprehensive assessment of the overall policy effects (Stolbova et al. 2108). Finally, they tend to neglect the positive externalities and co-benefits of climate mitigation and adaptation on green growth in the medium to long-term. Indeed, the transition to a low-carbon economy could lead to the development of new technologies, industry and markets, thus triggering a virtuous process of structural change in the economy (Foxon, 2017).

The economic and policy characteristics of the low-carbon energy transition require us to move beyond the equilibrium approach to display the drivers of agents' heterogeneity (e.g. differential access to public support and to credit) and their implications on endogenously generated business cycles, departing from the hypotheses of fully efficient market and rational expectations. In particular, we need macrodynamic models able to display the effect of a change in energy policy on the network of balance sheet relations characterising the economy and finance. This is fundamental for three reasons: i) to show emerging macroeconomic dynamics driven by a change of energy policy in the system, ii) to identify the origins of distributive effects that might create winners and losers associated to specific energy policies, iii) to provide a more realistic representation of the role of credit and finance in agents' investment decisions. Agent-Based and SFC models represent a promising alternative to traditional approaches because they allow to assess the direct and indirect effects of endogenously generated policy shocks in the context of incomplete or imperfect markets, asymmetric information and the departure from agents' full rationality. They include (with different level of detail) the credit and financial sector in relation to the other agents and sectors of the real economy, a government and a central bank. These features are important because they allow to provide a comprehensive socio-economic and financial assessment of the implications of energy policies. 


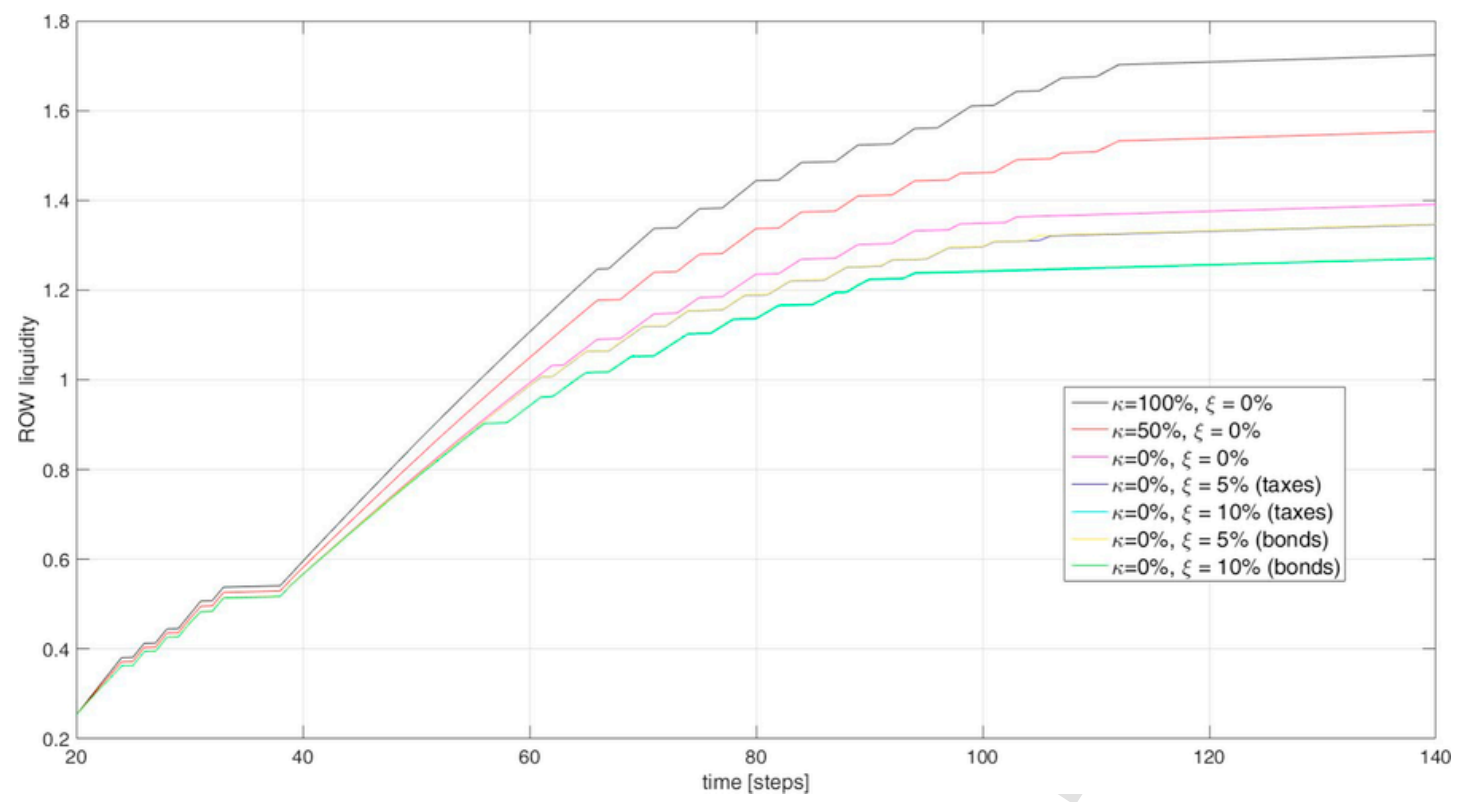

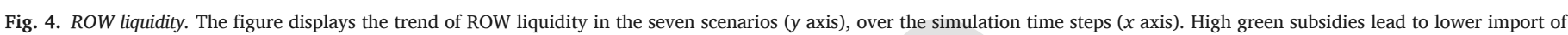
raw materials from ROW.

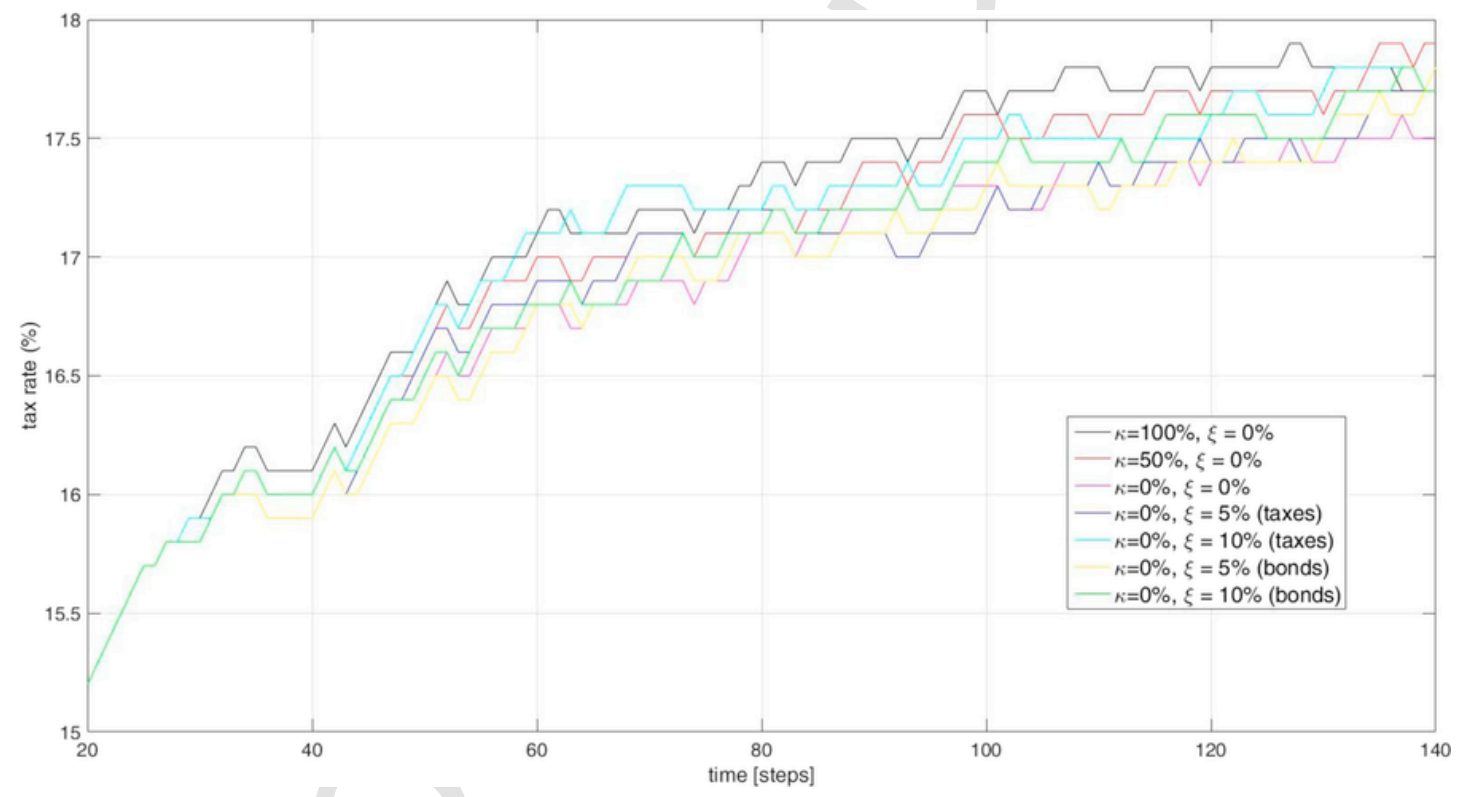

Fig. 5. Tax rate. The figure displays the trend in general taxation ( $y$ axis) over the time steps of the model's simulations ( $x$ axis).

\section{Methodology}

In this article, we develop an enriched version and a new application of the EIRIN model (Monasterolo and Raberto, 2018). EIRIN combines a SFC framework, which allows us to keep a rigorous accounting and to identify feedback loops between the real and financial sectors of an economy, with a Post-Keynesian approach to monetary economics. The focus on the behavioral and financial aspects of energy policies represents a novelty in the Post-Keynesian tradition on which the model is grounded (Caverzasi and Godin, 2014; Dafermos et al., 2017; Bovari et al., 2018; Ponta et al., 2018).

With EIRIN, we want to answer to two research questions that are relevant for energy policy:
1. To what extent could the phasing out of fossil fuel subsidies contribute to decarbonize the economy by influencing agents' investment behaviour?

2. Under which conditions could distributive effects of energy policies emerge (and who are the winners and losers) in the economy?

EIRIN represents agents and sectors in terms of interconnected balance sheets (Godley and Lavoie, 2007; Lavoie, 2014) to provide a full account of assets and liabilities of economic agents and sectors. EIRIN's agents and sectors are not constrained by strong behavioral assumptions but are heterogeneous in terms of preferences and characterized by bounded rationality, imperfect information and coordination. Further, EIRIN makes explicit consideration of finance and credit and their interaction with the energy sector, the real economy and public policies. Stock-Flow Consistency, balance sheet accounting and monetary 


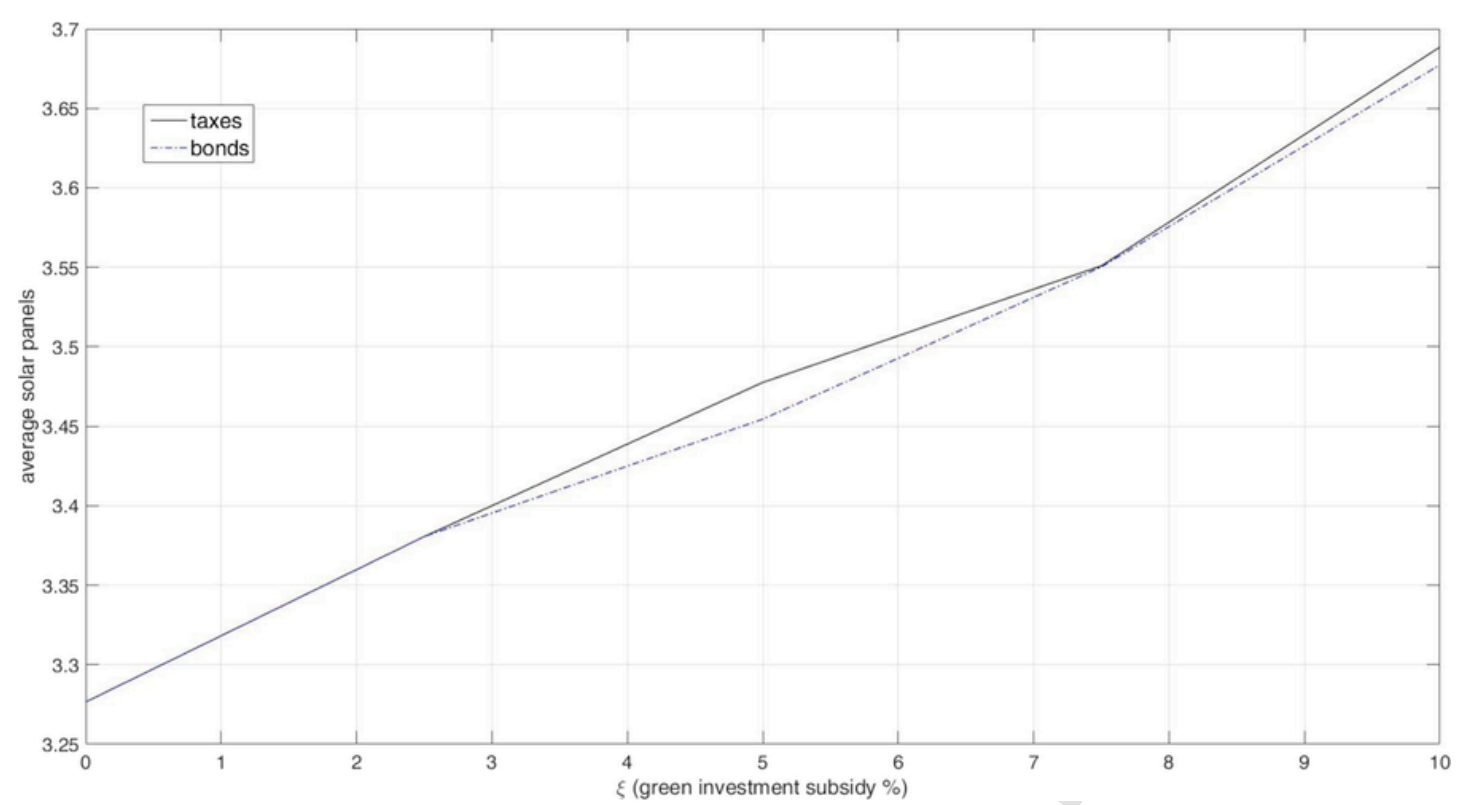

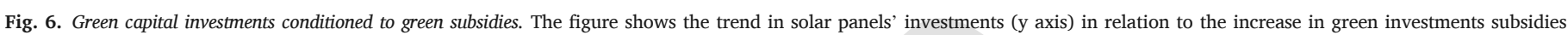
(either fiscal and bonds), set by the value of $\xi$ (x axis).

flows allow us to identify the structural channels of energy policy's transmission to the real economy and finance. By including a banking sector that provides credit as endogenous money (Lavoie, 2014; McLeay et al., 2014) and purchases green or brown bonds issued by the government, and a central bank in charge of conventional and unconventional monetary policies, we can analyze the overall economic policy impact considering all the agents and sectors involved (and not only those targeted by the policy). By displaying the policy impact $o$ in terms of changes in agents' balance sheets and their effects on real and financial flows, we are also able to assess their distributive effects in terms of winners and losers. Further, by relaxing strong assumptions on agents' rationality and intertemporal utility maximization as well as on market clearing prices and equilibrium conditions, we can display the endogenous drivers of economic business cycles, and their potentially unintended effects. In conclusion, our approach allows to fully address the interplay between the credit system, public policies and the real economy. As a difference from large scale Agent-Based Models, EIRIN allows to understand the causality chains while being parsimonious in complexity.

\subsection{EIRIN's agents and characteristics}

We briefly recall the main characteristics of the original model.

\subsubsection{Heterogeneous households}

By building on Goodwin (1967) and the Lotka-Volterra's predator-prey model, the households' sector includes two income classes, i.e. a worker class (Hw) and a capitalist class (Hk). Each class is represented by a separate agent/sector, i.e. a worker agent and capitalist agent. Households are heterogeneous not only in terms of income level and source but also in terms of access to financial markets. Indeed, only Hk receives dividends from consumption and capital goods firms, from mining and utility companies, and from the bank, and can purchase bonds.

\subsubsection{Heterogeneous capital goods producers (KGP) and goods}

EIRIN includes green and a brown KGP, which produce heterogeneous capital goods, respectively green and brown. Green capital goods allow a more resource-efficient production process than brown goods. ${ }^{4}$ This solution allows us to model the role of raw materials' cost on CGP's investments decisions about brown or green capital goods.

\subsubsection{A consumption goods (CGP) producer}

CGP makes investments decisions - in either brown (resource-intense) or green (resource-resilient) capital goods - based on the Net Present Value (NPV), which is influenced by the interest rate set by the central bank, by government's fiscal policy and subsidies. This point is particularly important because it allows to understand agents' intertemporal behaviour by comparing investments' short-term costs and long-term benefits, and it supports the representation of endogenous decision-making (e.g. the NPV of brown versus green investment decisions). We use NPV calculations to compare the present cost of investments, which are higher in the case of green capital goods, with the present value of future expected positive cash flows.

A commercial bank (BA) that provides loans to the consumption goods producer, to the mining and the utility companies. The bank has a target leverage (defined as the ratio between risk weighted assets and equity) to meet Basel III capital adequacy requirements ${ }^{5}$ and build resilience against borrowers' defaults.

A foreign sector (ROW) that provides raw materials in infinite supply to the domestic economy at an exogenously given constant price, in order to meet the production needs in the brown sector.

A government (G) that decides on the fiscal policy (i.e. sets the tax rates) to meet its budget balance target. In addition, $G$ issues brown bonds to cover its regular expenses, and issues green bonds to support capital investments in renewable energy production. Both green and brown bonds are defined as a perpetuity.

A Central Bank (CB) that sets the interest rate according to a Taylor-like rule. The interest rate depends on the inflation and output gap, measured as employment gap (i.e. the distance to a target level of employment), and influences investments through the NPV. The CB provides liquidity to BA in case of shortage of liquid assets.

\footnotetext{
4 We assume that the initial stage of development of the green capital goods is characterized by higher deployment of R\&D (i.e. solar panels innovation), followed by its application (e.g. the assemblage of solar panels).
}

5 https://www.bis.org/bcbs/basel3.htm. 

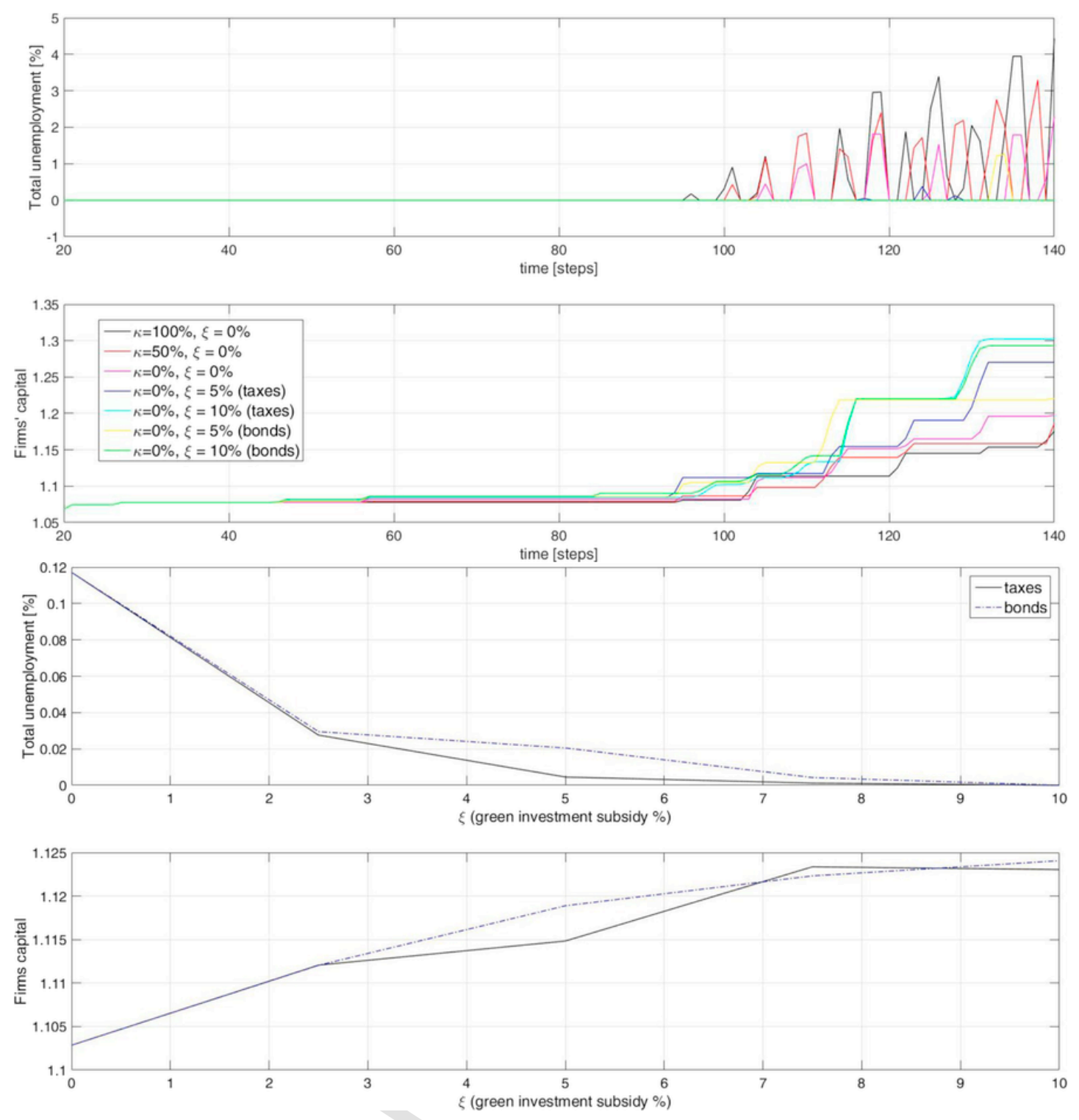

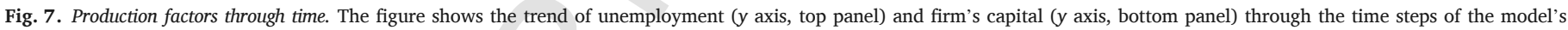
simulations ( $x$ axis) across the seven energy policy scenarios.

The complete details about the original model are provided in Monasterolo and Raberto (2018), which has been enriched in this study with an energy market and its agents, namely a mining company, a brown utility and a green utility company. These new features of the EIRIN model will be described in detail in the following sections and are displayed in the model structure (Fig. 1).

\subsection{EIRIN's markets}

EIRIN's agents and sectors interact with each-others and with the foreign sector through a set of markets, i.e. consumption and capital goods markets, labour, energy, oil and raw materials markets. EIRIN makes also explicit consideration of the credit and bonds market and their interactions with the energy sector, the real economy and the government.

Demand and supply formation, as well as pricing, are independent in each market at any given simulation step, with the exception of the credit market, where demand depends on the demand for capital goods. In each market, pricing is made by the supply side as a mark-up on unit costs, with the exception of the average price of labour, i.e. the average nominal wage determined according to a Phillips curve-like rule (Keen, 2013).

The key sequence of events occurring in each simulation step is the following:

1. Policy makers take their policy decisions. The $\mathrm{CB}$ sets the policy rate according to a Taylor-like rule while the government adjusts the tax rates on households' labour and capital income, and on corporate earnings, to meet its budget deficit targets.

2. All markets, exception for the credit market, open in parallel. Prices of the exchanged goods or services are determined, then the nominal or real demand and supply are provided by the relevant agent in each market. Finally, transactions occur generally at disequilibrium, i.e. at the minimum between demand and supply. The credit market opens after the capital goods markets. The possible rationing of credit supply affects the effective demand in the capital goods market by the consumption goods producer, the mining company and the green utility. 


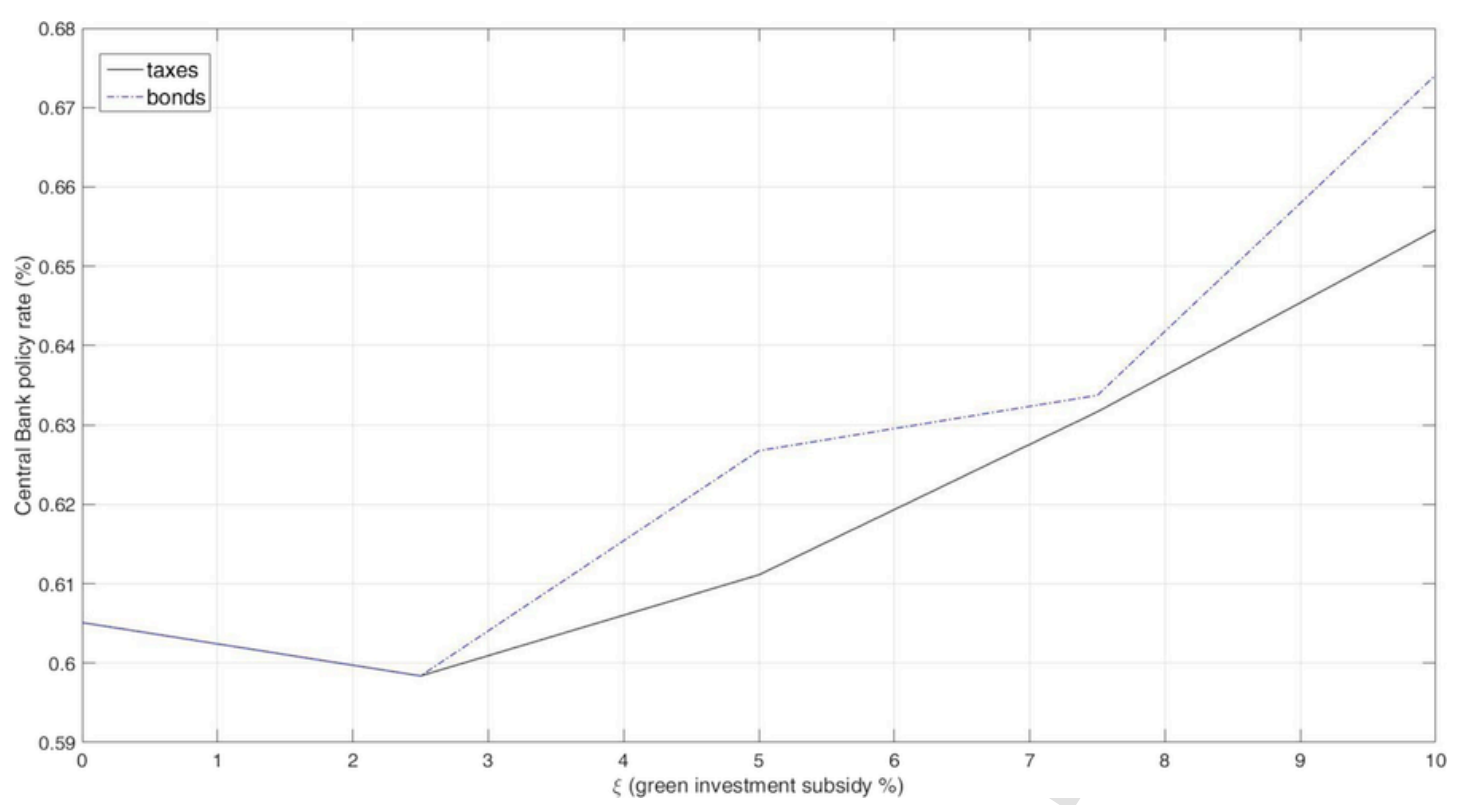

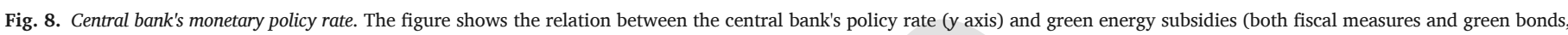
$x$ axis).

3. All transactions and monetary flows are recorded and the balance sheets of the agents and sectors of the EIRIN economy are updated accordingly.

\subsubsection{Consumption and capital goods markets}

The consumption and capital goods markets are mainly characterized by the same behavioral equations considered in the first version of the EIRIN model (Monasterolo and Raberto, 2018). The demand side of the consumption goods market is made by both the worker $(\mathrm{Hw})$ and the capitalist agents (Hk), which set their nominal demand for the homogeneous consumption good, $C_{H w}$ and $C_{H k}$, according to the buffer stock theory of consumption (Deaton, 1991; Carroll, 2001), i.e. based on both net income, $Y_{H w}^{\text {net }}$ and $Y_{H k}^{\text {net }}$, and liquid wealth, $M_{H w}$ and $M_{H k}$. In particular, $C_{H w}$ and $C_{H k}$ are determined according to equation (Eq.) number 9 and 10, respectively, in Monasterolo and Raberto (2018). However, we include a difference in comparison to the previous version of the model, i.e. the net income, $Y_{H w}^{\text {net }}$ and $Y_{H k}^{\text {net }}$, is replaced with the disposable net income, $\left(Y_{H w}^{n e t}-p_{e} q_{e}^{H w}\right)$ and $\left(Y_{H k}^{n e t}-p_{e} q_{e}^{H k}\right)$, where $p_{e} q_{e}^{H w}$ and $p_{e} q_{e}^{H k}$ are the newly-introduced energy expenses, to be subtracted from net income to determine the consumption budget for goods.

On the supply side, the amount supplied by the CGP is determined by the inputs made available at the previous step i.e. the share of employed workforce $N_{C}$, the endowment of physical capital $K_{C, j}$ and the Leontief technology (Leontief, 1941) according to Eq. 12 in Monasterolo and Raberto (2018). Raw materials $q_{R}$ imported from the ROW at an exogenously given constant price $p_{R}$ represent the third input used by the CGP. Nevertheless, assuming raw materials are in infinite supply, the CGP is never rationed on its import. Thus, raw materials are not binding for the production plans but influence the unit costs of production. The CGP sets prices as a fixed mark-up on unit costs, which include the labour cost $w_{\text {brown }} N_{C}$, the raw material cost $p_{R} q_{R}$ and the interest expenses $r_{D}$ Loans $_{C}$ on outstanding debt Loans $C$, per unit of output. The transaction takes place at the minimum between demand and supply. One side of the market is usually rationed. If rationing applies to the demand side, then this is distributed to the worker agent and the capitalist agent proportionally to their demand. Finally, based on the sales at the previous time steps and on its inventory level, the CGP makes the production plan for the next simulation step.
As for the capital goods market, there are two new actors on the demand side with respect to the first version of EIRIN (Monasterolo and Raberto, 2018), i.e. the green utility company and the mining company. The green utility company' demand is green capital, which is identified as solar panel units, while the mining company's demand is brown capital goods. ${ }^{6}$ On the supply side, there are two capital goods production sectors, i.e. the green and the brown one, which produce on demand and set their respective capital goods prices, i.e. the price of green capital goods $p_{K_{g}}$ and the price of brown ones $p_{K_{b}}$ based on labour unit costs, i.e. $w_{\text {green }} N_{K_{\text {green }}}$ and $w_{\text {brown }} N_{K_{\text {brown }}}$, where the money wage is higher in the green sector, i.e. $w_{\text {green }}>w_{\text {brown }}$. In addition, the demand side in the capital goods market is made by the consumption goods sector. Based on its production plan and the Leontief technology, the CGP determines its target level of capital endowment, and then it sets the level of investment $I_{C, K_{j}}$, i.e. the demand for capital goods either brown or green, accordingly. The target level of capital endowment is defined by considering its present endowment of physical capital and the capital depreciation rate. The choice between investing in green or brown capital goods is made according to the highest NPV between green and brown expected investment cash flows, considering also the size of government subsidies $\mathrm{G}$ for green capital investments. ${ }^{7}$

\subsubsection{Labour market}

The demand side of the market is made by the consumption and the capital goods sectors, plus the government. In order to limit the complexity of the model, we assume that both the brown and green utilities as well as the mining company do not employ workers as a production factor. The labour demand by the government is a new feature of this enriched version of the model. It has been introduced not only for the sake of realism but also to take into account i) a baseline level of expenses by the public sector, other than interests on debt or green subsidies, and ii) a baseline source of income for Hw. In particular, we assume that the government demands a constant fraction $\gamma_{G}$ of the total workforce provided by $\mathrm{Hw}$ at the $w_{\text {brown }}$ wage rate.

\footnotetext{
6 Further details are provided in the paragraph on the energy markets.

7 Further details and the behavioral equations related to the capital goods producers and the investment demand of the CGP are provided in Monasterolo and Raberto (2018).
} 
The CGP's labour demand is set according to its production plans and to the Leontief production technology, see Eq. 21 in Monasterolo and Raberto (2018). Labour demand by the green or brown KGPs depends on the demand for investment received on the previous time step and on labour productivity (see Eq. 22 in Monasterolo and Raberto, 2018).

The labour force, which is supplied by $\mathrm{Hw}$, is fixed, inelastic to wage and characterized by a continuum of skills, which are uniformly distributed from a lower to an upper bound (See Appendix B in Monasterolo and Raberto, 2018). The average nominal wage is determined according to a Phillips curve-like rule (Keen, 2013), where the percentage change in the nominal wage depends on the level of unemployment recorded in the previous time step. Given the average wage and a minimum wage (set as a parameter in the model), the wage levels in the brown (government, CGP, KGP brown) and in the green (KGP green) sectors, i.e. $w_{\text {brown }}$ and $w_{\text {green }}$ are determined so to satisfy the condition $w_{\text {green }}>w_{\text {brown }}$ and to guarantee that the wage bill of the economy does not depend on the labour force allocation in the brown/green sectors but only on its employment level, consistently with the setting mechanism for the average wage. Full details are provided in Section 2.5.3. "Money Wage Setting" in Monasterolo and Raberto (2018). The labour transaction is set at the minimum between demand and supply. In the case of rationing on the demand side, we assume that the public sector has priority over the private sector agents, then the green KGP has priority on labour supply over the brown one, which in turn has priority on the CGP sector. Finally, we assume that the KGP green always hires the skilled fraction of the labour force. ${ }^{8}$

\subsubsection{Energy market}

The main novelty on the previous version of the EIRIN model that allow us to simulate energy policies is represented by the introduction of an energy market connected to the real economy, the credit system and the government. With the aim to provide a clear yet comprehensive and realistic structure of the energy market, thus strengthening the consistency and reliability to our model, we move from the Global Climate Assessment Models (GCAM) structure (Thomson et al., 2010). ${ }^{9}$ The supply side of the energy market is composed by heterogeneous agents characterized by fossil fuel-based production or by renewable energy production. Agents produce to meet the domestic demand for energy either through fossil fuels or renewable energy sources (i.e. solar and wind). The energy market is composed by:

- A mining company that extracts fossil fuels, i.e., oil, natural gas, or coal;

- A brown utility company that produces electricity using fossil fuels;

- A green utility company that produces electricity using renewable energy sources, i.e., solar power and wind.

The demand side of the energy market is given by the sum of the worker agent demand $q_{e}^{H w}$ and of the capitalist agent demand $q_{e}^{H k}$, i.e. by $q_{e}=q_{e}^{H k}+q_{e}^{H w}$. Both energy demands are assumed to be constant, consistently with the short-term horizon of our simulations. For the sake of simplicity, we don't consider the contribution of the production sector to the demand of energy, in order to detach the performance of green subsidies from the effects of the business cycle. In the further development of the model, we will include the production sector into the energy demand function.

8 For details on the wage setting and the distribution of skills among the labour force, see Monasterolo and Raberto (2018).

9 For a full reference to the GCAM model: http://www.globalchange.umd.edu/ archived-models/gcam/.
The supply side is made by both a non-renewable (brown) $q_{e}^{n r}$ and a renewable (green) $q_{e}^{r}$ contribution, supplied by the brown and the green utility companies, respectively. We assume that the green utility company has priority in the grid and that the brown utility company is always able to meet the residual energy demand, i.e.

$q_{e}^{n r}=q_{e}-q_{e}^{r}$

The green utility supply of renewable energy is set by its green capital endowment (i.e. the number of solar panels, $n_{s p}$ ), i.e. $q_{e}^{r}=\varepsilon_{s p} n_{s p}$, where $\varepsilon_{s p}$ is the amount of energy produced by each solar panel at each simulation step. The brown utility produces electricity $q_{e}^{n r}$ by means of a non-renewable resource (e.g. oil) supplied by the mining company, and a production technology characterized by constant returns to scale, i.e. $q_{e}^{n r}=\varepsilon_{o} q_{o}$, where $q_{o}$ is the quantity of oil necessary to produce $q_{e}^{n r}$ units of energy and $\varepsilon_{o}$ is the efficiency of the oil to energy transformation process.

The brown utility company sets the energy price $p_{e}$ based on a mark-up $\mu_{e}$ on its unit costs $c_{e}$, given by the oil price $p_{O}$, and the cost of debt service, i.e.

$c_{e}=\frac{p_{o} q_{o}+r_{D} D_{B U}}{q_{e}^{n r}}=p_{o} / \varepsilon_{o}+\frac{r_{D} D_{B U}}{q_{e}^{n r}}$

Accordingly, the energy price $p_{e}$ is set as

$p_{e}=\left(1+\mu_{e}\right) c_{e}$

The oil price is assumed to be determined in international markets and thus is modelled as an exogenous variable characterized by a constant growth rate $\mu_{0}$.

The green utility company (GU) undertakes green investments to increase its renewable energy production capacity. In particular, the green utility sector plans the purchase of new units of solar panels (or wind turbines), $\Delta \widetilde{n}_{s p}$, which are identified in the model as new units of green capital goods. To this purpose, the green utility company computes at any time step the NPV of acquiring $\Delta \widetilde{n}_{s p}$ units of solar panels at the price $p_{K_{g}}$ subsidized for $\xi \%$ by the government. The green utility company expects to be able to sell the new renewable energy produced at the latest market price $p_{e}$, assumed to stay constant in all future time steps. The effects of solar panel depreciation are considered as negligible in the short term run of the model.

The NPV is then given by:

$N P V=-(1-\xi) p_{K_{g}} \Delta \tilde{n}_{s p}+\frac{p_{e} \varepsilon_{s p} \Delta \tilde{n}_{s p}}{r_{D}}$

where $r_{D}$ shall be considered as the cost opportunity of capital and used to discount future cash flows and is proxied by the cost of debt. It follows that the lower the discount rate, the higher the investments in green capital goods (e.g. solar panels).

The sign of the NPV determines the decision to undertake the investment or not, whereas the planned investment amount, i.e. $\Delta \widetilde{n}_{s p}$, is set ${ }^{10}$ by the available liquidity of the green utility company, i.e. $M_{G U}$, plus the possibility to take new debt $\Delta D_{G U}$ with the bank given a constraint on the maximum allowed leverage $\alpha_{G U}$. Accordingly, if $N P V>0$ we have:

$$
\begin{aligned}
\Delta \tilde{n}_{s p}= & \frac{M_{G U}+\text { Loans }_{G U}}{p_{K_{g}}} \text { holdingthat } \Delta \widetilde{\text { Lans }_{G U}} \\
& + \text { Loans }_{G U} \\
= & \alpha_{G U} E_{G U}
\end{aligned}
$$

10 It is worth noting that the NPV cannot be used to determine the optimal amount of investments since the net present value is monotically dependent on $\Delta n_{s p}$. 
otherwise if $N P V \leq 0$, then $\Delta \widetilde{n}_{s p}=0$. It is worth noting that investments in renewable production capacity are positively influenced by the green subsidy rate $\xi$ to green capital investments, i.e. a policy parameter, and by the market price of energy, $p_{e}$.

Concerning the brown utility company (BU), for the sake of simplicity, we assume that no investments and no capital depreciation occur in the short-term space of our simulation. Accordingly, we assume that the level of (brown) physical capital and debt remain constant, i.e. $\Delta K_{B U, b}=0$. Profits made on the mark-up on the oil price are paid out to the capitalist household ( $\mathrm{Hk}$ ) as dividends. Being $d_{B U}$ the aggregate dividend, the amount paid out to the $\mathrm{Hk}$ is then given by:

$d_{B U}=p_{e} q_{e}^{n r}-p_{O} q_{O}-r_{D} D_{B U}$

if positive, or zero otherwise.

As far as the mining/oil company (mi), we assume that investment plans in brown capital goods are simply aimed to cover capital depreciation at rate $\xi_{K}$ i.e.

$\widetilde{I}_{m i, K_{b}}=\xi_{K} K_{m i, b}$,

in order to keep constant over time the endowment of physical capital, i.e. $\Delta K_{m i, b}=0$.

Net operating profits of the mining company are paid out as dividends to shareholders, which are both the domestic capitalist (Hk) and the foreign sector (ROW). Being $d_{m i}$ the aggregate dividend, the amount paid out to shareholders is then given by:

$d_{m i}=p_{O} q_{O}-r_{D}$ Loans $_{m i}-\mathrm{T}_{m i}$

if positive, or zero otherwise. $\mathrm{T}_{m i}$ sets the amount paid by the mining company and defined as:

$\mathrm{T}_{m i}=(1-\kappa) \tau\left(p_{O} q_{O}-r_{D}\right.$ Loans $\left._{m i}\right)$

where $\tau$ is the general tax rate, while $\kappa$ sets the fossil fuels subsidy policy, e.g. with $\kappa=100 \%$ the mining company is fully exempt from the taxation of its corporate profits. It is worth noting that corporate profits of the bank agent and of both utility companies, green and brown, are not taxed by model construction, for the sake of simplicity.

The share of profits paid out to foreign shareholders depends on the share $\gamma_{O}$ of ownership of the mining company by the foreign sector and sets the financial dependency on ROW of the EIRIN economy for the provision of non-renewable energy sources.

\subsubsection{Credit marke}

The bank agent provides loans to real economy agents who may be in need to borrow money to finance their investment plans or a liquidity shortage. Loans are provided at rate $r_{D}$, which is based on the central bank policy rate $r_{C B}$ plus a mark-up. It is worth remembering that the central bank policy rate $r_{C B}$ is set according to a Taylor-like rule, see Eq. (1) in Monasterolo and Raberto (2018). The borrowers are the CGP sector, both the brown and green utility companies and the mining company. The CGP agent undertakes investments in capital goods either green or brown, depending on NPV considerations, see section 2.5.6. "Investment Demand" in Monasterolo and Raberto (2018) for the full details. We assume that CGP's investments are fully financed by new loans. For this purpose, the CGP agent requests a loan $\widetilde{\Delta \text { Lans }_{C}}$. As discussed in the previous section, the green utility invests in new green capital goods (say solar panels) to increase its renewable energy production capacity, see Eq. (5), whereas the mining company make investments in new brown capital goods simply to replace capital depreciation, see Eq. (7), then the amount $\Delta \widehat{\text { oans }_{m i}}$ requested for loan is set to $\Delta$ Lans $_{m i}=\widetilde{I}_{m i, K_{b}}$. Finally, the brown utility company requests a loan amount $\widehat{\Delta \text { Lans }_{m i}}$ in the case of liquidity shortage.
The bank (BA) is subject to a capital adequacy requirements (CAR), consistently with Basel III. Thus, credit may be rationed due to insufficient equity capital on BA's side. In case of rationing, credit is allocated proportionally to the demand schedules of the CGP, the green utility and the mining company. Thus, the effective credit received $\triangle$ Loans $_{\{C, G U, m i, B U\}}$, may be lower than the amount demanded $\Delta \widetilde{\text { Loans }}_{\{C, G U, m i, B U\}}$. In this case, agents may revise their investment plans downward accordingly, and reduce the capital goods demand, either brown or green. The investment made by the green utility company, i.e. $\Delta n_{s p}$ and by the mining company, i.e. $\widetilde{I}_{m i, K_{b}}$ could be lower than the one initially planned, i.e. $\Delta \widetilde{n}_{s p}$ and $\widetilde{I}_{m i, K_{b}}$, respectively. In the case of credit rationing, BA stops paying dividends in order to increase its equity capital.

\section{Model scenarios}

We simulate seven scenarios that imply the introduction of three sets of energy policies:

- Two scenarios with a gradual phasing out of fossil fuel subsidies. At the initial time of the simulation, the mining company benefits from fossil fuel production subsidies via tax allowances. The mining company is subject to the same endogenous gross earnings tax rate $\eta$ applied to all private companies but we assume that it gets a tax rebate equal to $\kappa \%$ of its tax bill as a consequence of the subsidy. We consider two different decreasing levels of tax rebate $\kappa$, i.e. $\kappa=100 \%(\mathrm{~S} 1)$ and $\kappa=50 \%$ (S2).

One scenario of full phasing out of fossil fuel subsidies: $\kappa=50 \%$, no green policy (S3).

Two "green subsidy/fiscal" scenarios where the government gradually phases in subsidies for investments in renewable energy production capacity, covering the cost of the subsidy through general taxation in order not to affect its budget balance. The subsidy covers a fraction $\xi$ of the cost of a solar panel unit. We consider two increasing levels of subsidies, i.e. $\xi=5 \%$ (S4) and $\xi=10 \%$ (S5). In both S4 and S5, $\kappa$ $=0 \%$.

- Two "green subsidy/green bond" scenarios. The government chooses to subsidize the green capital investments by issuing green bonds, which are characterized by a clear conditionality. All the green sovereign bonds issued are bought by the commercial bank. We consider two increasing levels of subsidies, i.e. $\xi=5 \%$ (S6) and $\xi=10 \%$ (S7). In both S6 and S7, $\kappa=0 \%$.

The government also issues brown bonds to finance its regular budget and cover the gap (if any) between its regular expenses (public sector wages, unemployment benefits and interests on outstanding public debt) and the revenues from regular taxation. We assume that all new issued brown bonds are purchased by the capitalist household (Hk). As a consequence of the purchase, Hk needs to revise its saving rate (increase) and its demand for consumption goods (decrease).

We decided to start modelling green sovereign bonds because they allow us to focus on the "entrepreneurial" role of the government in opening and creating new markets (in this case, the green energy market) by decreasing risk perception of private investors by assuming risks that the privates may not afford (Mazzucato, 2013). In addition, several countries also in the EU (e.g. Poland, France and recently Belgium) started to issue green bonds to support renewable energy and energy efficiency investments.

Each scenario is represented in the figures with a different colour. The simulations are 140 steps long. ${ }^{11}$

\footnotetext{
11 The time steps are indicative and are not specified in real terms (e.g. months).
} 
In the first 20 steps, there is no differentiation among the seven scenarios, which are characterized by the same parameters values, i.e. $\kappa$ $=0 \%$ and $\xi=0 \%$ to address the transient period of the simulations. This parameters' setting corresponds to scenario (S3) characterized by no green subsidies and by no tax rebates to fossil fuels-based energy production.

At step 20, six new policies are activated. A policy's greenium occurs moving from S3 to S7, starting with a full phasing out of fossil fuels ( $\kappa=$ $0 \%$ ) then increasing green subsidies $\xi=5 \%, 10 \%$. The new scenarios give rise to different endogenous macroeconomic dynamics over time as regards the accumulation of renewable energy production capacity, investments, saving and borrowing decisions.

Table 2 shows the values of the parameters of the new energy market's agents.

\section{Results}

Fig. 2 to Fig. 8 show the macroeconomic, credit and bonds' market results of the simulation across the seven energy policy scenarios (Table 3).

Fig. 2 displays a clear positive effect of the phasing in of green subsidies on the production of renewable energy capacity, in particular in the two scenarios characterized by the highest level of green subsidies (i.e. $\xi=10 \%)$. We notice no considerable difference between the fiscal and the green bonds instruments (i.e. the green and cyan lines). In contrast, renewable energy production remains at the lowest levels in the scenarios characterized by fossil fuel subsidies (black, red and pink lines). The two scenarios with $\xi=5 \%$ (yellow and dark blue lines) set in the middle.

BA's balance sheet improves with the gradual phasing out of fossil fuel subsidies and the phasing in of green subsidies. In the scenarios characterized by the highest levels of green subsidies, and in particular in the green bonds scenario (light green line), BA experiences increasing deposits (top right panel) as a result of new loans, consistently (mid left panel) with the endogenous money creation. In addition, we see that BA's deposits and liquidity (top left panel) are influenced by the raw materials' import bill, and show the worst trend in the full fossil fuel subsidies' scenario (black line). Indeed, the import of raw material from ROW represents exported wealth from the domestic economy that, in turn, leads to lower investments in the domestic economy and thus to lower deposits (Figs. 4-6).

The ROW liquidity increases the most in the full fossil fuel subsidies' scenario (black line) due to the import costs of raw materials faced by the domestic economy. In contrast, import costs are the lowest (and thus is ROW liquidity) in the green scenarios, in particular for those characterized by highest green subsidies (light green and cyan lines). Indeed, in these scenarios the economy starts to decarbonize, substituting fossil fuels with renewable energy for production and consumption.

Scenarios with highest public policy intervention in the energy market, in particular full fossil fuel subsidies (black line), display the highest increase in general taxation because the government finances the subsidy through an increase in general taxation to keep the budget balance. The variation pattern within the same scenario is a result of endogenous dynamics driven by agents and sectors' decision, which are not constrained by assumption by full rationality and perfect coordination.

Green investments subsidies, either financed through fiscal measures or through the issuance of green sovereign bonds (represented by the value of $\xi$ ) influence agents' investments decisions in green capital units. The average installed production capacity grows monotonically for most values of $\xi$. The size of installed renewable production capacity, i.e. the number of solar panels, is computed as an average from step 20 to step 140 , for grid values of $\xi$ ranging from $0 \%$ to 10 .
The phasing out of fossil fuel subsidies contributes to improve the performance of the production factors, represented by unemployment (top panel) and firms' capital (bottom panel). In the case of full fossil fuel subsidies (black line), the economy experiences the highest unemployment and the lowest firm's capital accumulation because the subsidies are fully financed via general taxation, thus depressing other investments (bottom panel) and consumption. In addition, since the country needs to import raw materials and fossil fuels from ROW, a carbon-intense economy means an outflow of liquidity to the foreign country. In contrast, the phasing in of green subsidies contributes to increase capital accumulation and employment (see Fig. 7a for details).

Fig. 7a: Production factors conditioned to green subsidies. Fig. 7a shows the effects on the production factors ( $y$ axis) of increasing levels of green fiscal policy and green sovereign bonds issuance ( $x$ axis).

Higher levels of green subsidies lead to positive economic outcomes in terms of lower unemployment (top panel) and higher speed of capital accumulation in the production sectors (bottom panel), thus supporting the development of the green economy. Nevertheless, the trend in the fiscal and green bonds' policy scenarios is slightly different. Our explanation is that the higher share of renewable energy production in the green subsidies scenarios implies lower fossil fuels extraction, thus lower revenues and profits for the mining company, and consequently lower money outflow to the ROW. In this way, the domestic economy displays higher purchasing power and domestic demand, with positive effects on unemployment rate and capital accumulation. This positive effect also emerges in BA's balance sheet (Fig. 3).

The interest rate set by the central bank could explain why the scenarios characterized by green subsidies financed with the issuance of green sovereign bonds are slightly less performing in terms of capital investments than the ones characterized by green fiscal policies. Indeed, the central bank's interest rate increases the most in the green bonds' scenarios, thus counteracting the inflationary trend created by the green bonds' issuance on the real economy. These results provide useful insights in the current discussion on what role, if any, central banks could play in the low-carbon transition by greening monetary policies.

\section{Conclusion and policy implications}

By applying an expanded version of the EIRIN SFC behavioral model, we find that reforming fossil fuel subsidies in high-income countries could create the conditions to foster a stable low-carbon energy transition, with positive socio-economic effects. Indeed, a gradual phasing out of fossil fuel subsidies contributes to shift investments to low-carbon energy production. In addition, it contributes to improve the real economy performance through higher capital accumulation in the domestic economy and the creation of green jobs and capital investments, supported by a dynamic credit market. Table 3 shows the impact of each policy and scenario to the real economy, green capital investments and the credit market.

The introduction of green subsidies supports renewable energy production in the domestic economy, and thus the green real economy, by influencing agents' investments decisions and expectations via their NPV. In the case of green capital investments, the subsidy share is more relevant than the way in which the green subsidies are financed. High general taxation or high issuance of green bonds characterise the most favourable scenarios for the accumulation of renewable production capacity. In contrast, fossil fuels subsidies, even at reduced levels, have a negative effect on green capital investments. They contribute to keep the domestic economy in a carbon-intensive path and to export domestic wealth to the foreign economy via the purchase of raw materials.

In the credit market, bank's deposits increase the most in the scenarios characterized by high green subsidies, in particular in the case 
of green bonds, as a result of new loans, consistently with the endogenous money creation. A greening of bank's deposits occurs because new loans are mostly related to the expansion of the renewable energy sector, contributing to decarbonize bank's balance sheet. In contrast, bank's deposits and liquidity are negatively influenced by the raw materials' import bill that characterises the scenarios with fossil fuel subsidies.

All energy policies have potential distributive effects, yet at a different extent. Moving from a full fossil fuel subsidies scenario to scenarios characterized by green subsidies, distributive effects across households and economic sectors decrease. The phasing out of fossil fuel subsidies make fossil fuel investments and energy production less profitable (according to the international market price) thus decreasing the profits of the mining and energy companies. This, in turn, leads to a decrease in the value of dividends paid to the capitalist household and in bank's deposits (and the value of interests paid back by the bank to the companies). Fiscal revenues increase because the mining and utility company start to pay full taxation to the government, which can now find fiscal space to support the introduction of green subsidies without worsening it budgetary conditions.

Finally, we should highlight that the issuance of green sovereign bonds leads to increase public debt. However, this debt is sustainable in the long-term because it is not debt for private consumption, which played a key role in the building up of the last financial crisis (Turner, 2017), but is debt for productive investments that help align the country's economy to the EU2030 targets. It stimulates green investments, which have a positive green multiplier effect on the economy, contributing to increase the tax revenues for the government, consumption, and employment.

Policy-relevant research is needed on the economic and financial implications of phasing out fossil fuel subsidies. At this regard, SFC behavioral models could represent a powerful tool to support governments in the difficult but fundamental task to reform their energy policies in alignment with the global climate objectives.

\section{Uncited references}

Carney, 2015; Raberto et al., 2018

\section{Appendix A. Supplementary material}

Supplementary data associated with this article can be found in the online version at doi:10.1016/j.enpol.2018.08.051.

\section{References}

Battiston, S., Mandel, A., Monasterolo, I., Schütze, F., Visentin, G., 2017. A climate stress-test of the financial system. Nat. Clim. Change 7 (4), 283.

Bast, E., Makhijani, S., Pickard, S., Whitley, S., 2015. The fossil fuel bailout: G20 subsidies for oil, gas and coal exploration. ODI-OilChange. Available from: 〈https://www.odi. org/sites/odi.org.uk/files/odi-assets/publications-opinion-files/9234.pdf $\rangle$

Bovari, E., Giraud, G., Mc Isaac, F., 2018. Coping with collapse: a Stock-Flow Consistent monetary macrodynamics of global warming. Ecol. Econ. 147, 383-398.

Burniaux, J.M., Chateau, J., 2014. Greenhouse gases mitigation potential and economic efficiency of phasing-out fossil fuel subsidies. Int. Econ. 140, 71-88.

Caldecott, B.L., McDaniels, J., 2014. Stranded generation assets: implications for European capacity mechanisms, energy markets and climate policy. (Working Paper) Smith School of Enterprise and the Environment, Oxford.

Carney, M., 2015. Breaking the tragedy of the horizon. Speech at Lloyd's of London, 29th September, Bank of England speech repository, 2015.

Carroll, C.D., 2001. A theory of the consumption function, with and without liquidity constraints. J. Econ. Perspect. 15 (3), 23-45.

Caverzasi, E., Godin, A., 2014. Post-Keynesian stock-flow-consistent modelling: a survey. Camb. J. Econ. 39 (1), 157-187.

Coady, D., Parry, I., Sears, L., Shang, B., 2017. How large are global fossil fuel subsidies?. World Dev. 91, 11-27.
Dafermos, Y., Nikolaidi, M., Galanis, G., 2017. A stock-flow-fund ecological macroeconomic model. Ecol. Econ. 131, 191-207.

Dartanto, T., 2013. Reducing fuel subsidies and the implication on fiscal balance and poverty in Indonesia: a simulation analysis. Energy Policy 58, 117-134.

Davis, L.W., 2014. The economic cost of global fuel subsidies. Am. Econ. Rev. 104 (5), 581-585.

Deaton, Angus S., 1991. Saving and liquidity constraints. Econometrica 59, 1221-1248.

del Granado, F.J.A., Coady, D., Gillingham, R., 2012. The unequal benefits of fuel subsidies: a review of evidence for developing countries. World Dev. 40 (11), 2234-2248.

Dennis, A., 2016. Household welfare implications of fossil fuel subsidy reforms in developing countries. Energy Policy 96, 597-606.

Fay, M., Hallegatte, S., Vogt-Schilb, A., Rozenberg, J., Narloch, U., Kerr, T., 2015. Decarbonizing Development: Three Steps to a Zero-Carbon Future. World Bank Publications.

Foxon, T.J., 2017. Energy and Economic Growth: Why we need a new pathway to prosperity. Routledge.

Gerasimchuk, I., Bassi, A., Ordonez, C., Doukas, A., Merrill, L., Whitley, S., 2017. Zombie energy: climate benefits of ending subsidies to fossil fuel production. (Working Paper) International Institute for Sustainable Development, Geneva.

Goodwin, R., 1967. A growth cycle. In: Feinstein, Carl (Ed.), Socialism, capitalism, and economic growth.. Cambridge University Press, Cambridge, UK.

Godley, W., Lavoie M., 2007. Monetary economics. Palgrave, Macmillan.

Hoffert, M.I., 2010. Farewell to fossil fuels?. Science 329 (5997), 1292-1294.

IEA, 2015. Medium Term Renewable Energy Market Report. Market Analysis and Forecasts to 2020, Paris.

IPCC, 2014. Fifth Assessment Report (AR5). Contribution of working group II to the fourth assessment report of the Intergovernmental Panel on Climate Change.

Jewell, J., McCollum, D., Emmerling, J., Bertram, C., Gernaat, D.E., Krey, V., Paroussos, L., Berger, L., Fragkiadakis, K., Keppo, I., Saadi, N., 2018. Limited emission reductions from fuel subsidy removal except in energy-exporting regions. Nature 554 (7691), 229.

Keen, S., 2013. A monetary Minsky model of the Great moderation and the Great recession. J. Econ. Behav. Organ. 86, 221-235.

Lavoie, M., 2014. Post-Keynesian economics: new foundations. Edward Elgar Publishing.

Leaton, J., 2012. Unburnable carbon-Are the world's financial markets carrying a carbon bubble. Carbon Tracker Initiative.

Leontief, W., 1941. The Structure of American Economy. Harvard University Press, Cambridge, 1919-1929.

Lilliestam, J., Patt, A., 2015. Barriers, risks and policies for renewables in the Gulf States. Energies 8 (8), 8263-8285.

McGlade, C., Ekins, P., 2014. The geographical distribution of fossil fuels unused when limiting global warming to 2C. Nature 517 (7533), 187.

McLeay, M., Radia, A., Thomas, R., 2014. Money creation in the modern economy. Bank Engl. Q. Bull. 54 (1), 14-27.

Marques, A.C., Fuinhas, J.A., Pereira, D.A., 2018. Have fossil fuels been substituted by renewables? An empirical assessment for 10 European countries. Energy Policy 116, 257-265.

Mazzucato, M., 2013. The Entrepreneurial State: debunking public vs. private sector myths. Anthem, 2013.

Monasterolo, I., Raberto, M., 2018. The EIRIN flow-of-funds behavioural model of green fiscal policies and green sovereign bonds. Ecol. Econ. 144, 228-243.

Monasterolo, I., Raberto, M., 2016. Nocontest: Green VS. Brown subsidies under the TTIP. In: Trade in the Balance: Reconciling Trade andClimate Policy, Report of the Working Group on Trade, Investment, and Climate Policy, pp. 28-36.

Olson, M., 1977. The logic of collective action: public goods and the theory of groups. Harvard University Press, Cambridge, Mass.

Parry, I., 2018. Fossil-fuel subsidies assessed. Nature 554 (7691), 175

Ponta, L., Raberto, M., Teglio, A., Cincotti, S., 2018. An agent-based stock-flow consistent model of the sustainable transition in the energy sector. Ecol. Econ. 145, 274-300.

Raberto, M., Ozel, B., Ponta, L., Teglio, A., Cincotti, S., 2018. From financial instability to green finance: the role of banking and credit market regulation in the Eurace model. J. Evolut. Econ. 1-37.

Schwanitz, V.J., Piontek, F., Bertram, C., Luderer, G., 2014. Long-term climate policy implications of phasing out fossil fuel subsidies. Energy Policy 67, 882-894.

Soile, I., Mu, X., 2015. Who benefit most from fuel subsidies? Evidence from Nigeria. Energy Policy 87, 314-324.

Stiglitz, J.E., Stern, N., Duan, M., Edenhofer, O., Giraud, G., Heal, G., La Rovere, E.L., Morris, A., Moyer, E., Pangestu, M., Shukla, P.R., 2017. Report of the high-level commission on carbon prices. Carbon Pricing Leadersh. Coalit. 29.

Thomson, A.M., Calvin, K.V., Chini, L.P., Hurtt, G., Edmonds, J.A., Bond-Lamberty, B., Frolking, S., Wise, M.A., Janetos, A.C., 2010. Climate mitigation and the future of tropical landscapes. Proc. Natl. Acad. Sci. 107 (46), 19633-19638. https://doi.org/10. 1073/pnas.0910467107.

Trebilcock, M.J., 2014. Dealing with Losers: The Political Economy of Policy Transitions. Oxford University Press.

Turner, A., 2017. Between Debt and the Devil: Money, Credit, And Fixing Global finance. Princeton University Press.

Verkuijl, C., Piggot, G., Lazarus, M., van Asselt, H., Erickson, P., 2018. Aligning fossil fuel production with the Paris Agreement: insights for the UNFCCC Talanoa Dialogue. Policy Brief. Stockholm Environment Institute, Stockholm.

Whitley, S., Van der Burg, L., 2015. Fossil fuel subsidy reform: From rhetoric to reality. New Climate Economy, London and Washington, DC. Available at /http:// newclimateeconomy.report/misc/working-papers $\rangle$. All rights reserved New Climate Economy c/o World Resources Institute. 